\title{
Chapter 8 \\ When School Comes to Community: \\ Considering the Socioethnic Environment in Educational Reform for Gypsy \\ Populations in a French City
}

\author{
David Giband
}

Relationships between deprived neighborhoods and school are complex and diverse (Garner \& Raudenbush, 1991; Rickinson et al., 2004). These relationships are particularly problematic for Gypsy/Roma children whose school connection is filtered through the community in a time of growing sedentarization and severe impoverishment. For years, academic attention has focused on the urban context of Gypsy/ Roma groups in deprived neighborhoods and the problematic schooling of Gypsy pupils in southern France (Liégeois, 1997; O’Nions, 2010). Urban settlement leads to the loss of traditional resources, to a strong dependence on social assistance, and to the sociospatial marginalization of a community considered "the inside foreigners" (Tarrius, 1997, p.15). Gypsy/Roma families reject compulsory schooling because they fear a loss of identity, lack examples of school success, and experience school violence (symbolic and non-symbolic) and entry into the world of "paios" (non-Gypsy person ${ }^{1}$ ) as stressful. Drawing on a decade of research in the Gypsy neighborhoods of Perpignan (France), ${ }^{2}$ I here explore the dynamics of an educational

\footnotetext{
${ }^{1}$ All the translations are made by the author.

${ }^{2}$ Investigations rely on both quantitative and qualitative data. First qualitative investigations were conducted by the author under a research program ("La citoyenneté urbaine", French ministry of urban planning and ecology, under the supervision of Professor Agnès Deboulet) with more than 30 open and semi-structured interviews with educators, families, local activists and city officials (2007-2010). These first investigations were supplemented annually by further interviews, with a total of nine additional semi-structured interviews and six informal interviews (with teachers, parents and social workers). Quantitative data come from the examination of archives for the city department of education for priority urban areas, and for La Miranda Elementary school (archives from 2005 to 2016). Conducting interviews in a Gypsy neighborhood was not possible for a "French white" academic without the help of social workers and local activists in the city of Perpignan. Among them, the author wishes to thank Stéphane Henry (head of the city department
}

D. Giband $(\bowtie)$

Department of Geography and Planning, University of Perpignan, Perpignan, France e-mail: giband@univ-perp.fr

T. Freytag et al. (eds.), Space, Place and Educational Settings, Knowledge and Space 16, https://doi.org/10.1007/978-3-030-78597-0_8 
reform aimed at transforming individual and collective attitudes towards school among Gypsy/Roma families living in urban spaces of advanced social marginality (Wacquant, 2006). In Perpignan, Gypsy/Roma people are highly marginalized, living in a deprived urban environment (violence, unemployment, poor housing conditions, female-headed households, problematic night life) and following their cultural and customary rules and values. These play a crucial role in weak school performance. In 2005, city riots (mainly based in a central Gypsy/Roma neighborhood) caused municipal, community, and educational stakeholders to act. Policymakers implemented a national experimental policy in Perpignan from 2007 to 2015, in which they treated education as the cornerstone of necessary change. This public policy opened schools to their social and ethnic environment, as socioenvironmental settings were utilized as a performative tool for school achievement and success.

I follow two aims in this paper. Firstly, I seek to understand the complex matrix structuring relationships between school and the sociocultural environment of a marginalized group through a territorial approach. Territory, "territoire," is a concept French social geographers use to understand relationships between societies and their environments (Di Méo \& Buléon, 2005). I focus on the use of territory from a social-geography perspective (Séchet \& Veschambre, 2006), thus asking whether understanding the concept of territory as "a complex system whose characteristics and dynamics are based on the interactions" between actors and their spatially socioenvironmental settings provides an operational approach for understanding school/space/society interactions (Barreteau et al., 2016, p. 2). Secondly, I question the experiment of using inclusive cultural schools initiated for Gypsy/Roma populations in Europe in order to promote critical citizenship and to link schools to their territories, so that they become agents of social transformation. This experiment raises many questions. In which ways does the social and ethnic environment act as a lever for school attainment? Which kinds of social, (inter)cultural, and spatial interaction have been developed? What are the consequences for Gypsy pupils in respect of inherited cultural norms, educational frames of reference, and school achievement and success? Is this model replicable for other minority groups in a country where education is still designed on the basis of equity and republican national values?

I will first examine in which ways territory is a relevant concept in the understanding of dynamics between school issues and advanced marginalized socioenvironmental settings. I will subsequently examine contemporary urban educational issues for non-traveler Gypsy groups in Europe and in France. And, in light of the experiment initiated in a Gypsy neighborhood in Perpignan, I will discuss in which ways inclusive educational experiments, which open schools to their ethnic and cultural environment, are a performative tool for Gypsy/Roma educational achievement.

of education for priority urban areas) for his valuable help. He opened doors to Gypsy families and gave us free access to the archives. 


\section{Understanding the Role of Socioenvironmental Settings: A Territorial Approach}

French geographers use the concept of territory, the object of numerous scientific discussions and debates (Debarbieux, 2009; Di Méo, 1998; Fall, 2007), to study relations between individuals, groups, and their environment, and this concept can serve to elucidate the role of socioenvironmental settings in education (Debarbieux, 2009; Di Méo, 1998; Fall, 2007).

\section{For a Territorial Approach}

As Barreteau et al. (2016) have shown, the concept of territory has gained in popularity among French social scientists in the past three decades and is mostly used by social geographers. In social geography, it means a social and a lived space, including its political and ideological dimensions (Di Méo \& Buléon, 2005). Referring to Lefebvre (1974), social geographers understand territory in terms of the dialectics of social space. It refers to the idea of a social space which, through processes of identity and belonging, is socially appropriated and represented, carries ideologies and norms (social, cultural, religious, etc.), and is politically controlled. "Territory is socially produced, conflictual, and a medium for social representations" (Barreteau et al., 2016, p. 2). It also refers to "a holistic approach to account for the complexity of social phenomenon in their spatial dimensions. It describes how individuals and groups act, think, behave and implement strategies in a given controlled space" (Barreteau et al., 2016, p. 3). Its definition includes both material (physical environment) and immaterial dimensions (social representations and practices of a given space, images, imaginaries, ideas, etc.), which "are transforming space into territory, making it socially and culturally invested" (Barreteau et al., 2016, p. 4). It can be understood as a system connecting a physical space to a social game implemented by diverse actors (Ormaux, 2008), with a symbolic dimension generating collective identity and social belonging.

\section{Exploring Relations Between Education and Territory}

Relations between territory and education can be formalized under two main aspects. First, territory has to be understood as a context-one that impacts education via territorial effects (Champollion, 2015). As a context, territory functions as a socioenvironmental setting in which education develops, is structured, normed and regulated, and interacts with other social dimensions. This educational territorial context is shaped by both material elements (nature of the physical space, density, landscape, conditions of access to educational amenities) and social elements 
(poverty, wealth, perception of education as central or peripheral for a local society). Territory affects all educational and school parameters: school choice, educational trajectory, school achievement, education and vocational guidance, and so forth. For instance, the conductors of a study of school achievement in mountainous regions have revealed how specific geographical locations constrain the nature of teaching (difficult access to cultural or educational resources) and determine teaching practices (focused on relations with nature) and the nature of teaching professionality (Moracchini, 1992). Second, territory can be considered as an educational stakeholder in itself (Charlot, 1994). Some researchers underline the role of the local milieu as a provider of educational resources for teachers, parents, families, and educators. Feu and Soler (2002) declare that territory is a "new educational stakeholder," supplying formal and informal educational resources (via the presence of landscapes, cultural amenities, natural resources, etc.) and framing a relational space in which people involved in education can interact (educators, families, community or religious groups, etc.). As a stakeholder, territory not only explains specific educative situations (inequalities, school failures, etc.), but can be an (im) material support for mobilizations and actions in education. The territorial part of education refers to the symbolic dimensions in which education is spatially enshrined. These dimensions-nurtured in the spheres of the individual, family, community, and other collectives - are part of the making of territorial imaginaries of school. They are embedded in cultural and affective references that define the nature of educational territories for individuals and groups, depicting them as territories of school failure, school success, and so forth.

A territorial approach allows researchers to go beyond traditional analysis by comprising contextual factors influencing schooling that do not belong to sociological and institutional factors. Territory is an explanatory variable that researchers of education continue to underuse and neglect (Champollion \& Legardez, 2010). Utilizers can reveal the hidden sociospatial face of education that acts inside the educational process through its symbolic, affective identity, and strategic dimensions. By situating education within a specific territorial environment, they make visible and comprehensive the systematic interactions connecting individuals and their spatial practices, territorial imaginaries, educational representations, and expectations in respect of the physical space in which education occurs.

\section{School, Family Spaces, and Territorialities}

Researchers cannot understand spatial relationships connecting individuals and groups to education without referring to territorialities. Besides its legal nature, territoriality creates a strong sense of belonging and a mode of human behavior inside a spatial entity. It reflects collective and individual practices and an affective and emotional relationship to a spatial entity (place, neighborhoods, region, city, ...). Territorialities are diverse. Territorialities of teachers and parents are important elements in the dynamics of education. Social scientists have analyzed the 
territorialized part of teacher identity (Rothenburger, 2014), underlining the significance of professional representations regarding the school's sociospatial environment. It influences both their strategy of professional mobility and their pedagogical practices. In their practices, many teachers consider not only school performance and social composition, but also the territorial environment as a whole: neighborhood characteristics, ethnicity, and the symbolic dimension of the territory in which a school is located (wealthy, poor, ethnic neighborhood). The territoriality of parents is also an important factor. Multiple and diverse, parents' territoriality is rooted in a social environment in which parental relations to time, space, and social organization interfere with the nature of schooling and school achievement. Involvement in parent-teachers' associations is highly territorialized through complex interactions within the educational local system.

\section{Education and Territorial Ethnicity}

In many contexts, ethnicity appears as an important territorial dimension that needs to be explored, especially in deprived urban contexts where ethnicity plays a significant role between families and school. French sociologist Françoise Lorcerie (2009) proposed the concept of territorial ethnicity to understand the social and psychosocial processes shaping the connections between space and education in French priority education areas.

Territorial ethnicity refers to the formation of a social configuration taking place into a space where social factors (concentration of impoverished people, lack of jobs, social depreciation of the place for many reasons) are combined with intersubjective factors of ethnic visibility. (Lorcerie, 2009, p. 65)

Thus defined, researchers use territorial ethnicity to question the nature of social groups' backgrounds and their impacts on the local educational process. The term involves three main dynamics: (i) segregation (materialized in spaces of urban marginality and schools of social and ethnic relegation); (ii) the assignment of alterity to the minority population (families, pupils, residents) by the majority population; (iii) people's self-identification as a minority population, which allows individuals, families, and groups involved in education to elaborate "identity formulas" enabling them to act, contest, or organize themselves in the local educational space. This generates a double movement. First, school is troubled by its socioethnic environment. External stakeholders such as the school district, press, or teachers' union systematically give territorial ethnic and social attributes to schools, thus impacting their internal and external reputation. Second, school produces ethnicized representations that impact, on different scales, education's spatial organization. Internal and external dynamics of territorial ethnicity foster 'push-and-pull' logics (Lorcerie, 2009). Following pull logics, families seek the best school for their children according to its reputation and the quality of the teaching environment. And according to push logics, a large number of pupils with a visible (immigration or minority) 
background inside a school or a school district will tend to keep majority families away. These socioethnic categorizations of specific territories and their schools determine a school schema according to logics of alterity and otherness. "This school schema naturalizes the difficulties of learning by allocating them to what pupils, families and neighbourhoods are" (Lorcerie, 2009, p. 69). Territorial ethnicity thus fuels a complex interdependence game between the school and its surrounding socioenvironmental settings.

\section{Non-Traveler Gypsy Communities and the Educational Issue: A Matter of Territory?}

Both the authors of scientific literature and international institutions (such as UNESCO, European Council) issuing official reports well document the relations between Gypsy/Roma groups and education. They all report highly problematic relationships between families and compulsory education: low enrollment, weak attendance, limited education levels (literacy), poor expectations, fears of schooling, distrust of the education system, concentration of Gypsy/Roma pupils in specific schools and/or classrooms, recurrent drop-outs, and an early leaving age (especially among girls).

\section{Contemporary Educational Issues for Non-Traveler Gypsy Groups in Deprived Urban Settlements}

The European Council reports that about $50 \%$ of Gypsy/Roma are non-travelers, of whom a significant part has settled in urban locations. Urban settlements foster a complex relationship between former traveling communities and the school institution. As Rosário et al. (2017) have recently said in their study of Spanish Gypsies' urban locations: "[L]ow schooling, high non-attendance and school drop-out are critical phenomena among Gypsy populations in Europe" (p. 561). Urban settlements lead to growing impoverishment and enclosure inside deprived and blighted neighborhoods. Gypsy identity and social representations are linked to urban marginality and social exclusion, including at school. Enclosed in spaces of relegation, these groups face segregation policies and a longstanding cycle of social deprivation that transforms socioenvironmental settings into singular territories, with specific cultural, social, and moral dynamics and discriminatory institutional policies. All of these factors impact school and the relationships between the Gypsy groups and the school institution.

Most non-traveler Gypsy/Roma families in Europe develop a utilitarian view of school, reduced to basic notions of reading, writing, and calculating. Many scholars have noted that school does not fulfill the needs of Gypsy/Roma families. They still 
view school as an institution of the dominant society (García Pastor, 2009), as involving a process of depersonalization and as a place of violence (symbolic and institutional) against pupils. As a space of contact with the rest of society, school is also a place where these groups face racism, and where "mutual prejudices" contribute to separating them from the rest of society (García Pastor, 2009). For these groups, the distance separating families from school can be measured by the families' attachment to traditional values, their insistence on belonging to the group rather than the individual promotion offered by school.

At school, the individual is enhanced for his academic performance. It is a form of individual promotion. For Tziganes and travelers, the child, the adult only exist as part of the group, by the place he stands in the group and the function devolved. (Liégeois, 1985, p. 160)

School is understood as a place where the Gypsies/Roma lose their identity, whereas the closed space of their community guarantees affective, material, and symbolic security for the whole group (Faure, 2004). In many European countries, they live in spaces of relegation with poor employment opportunities, deteriorating socioeconomic conditions, and few public amenities and infrastructures. These conditions of life directly impact schooling and school achievement: limited access to education, school dedicated to Gypsy/Roma pupils with limited standards, patchy attendance, dropping out, no social mixing, poor marks, and so on. In the European Union (EU), Roma/Gypsy children constitute the most vulnerable group in terms of educational issues. About $50 \%$ of Roma/Gypsy pupils are daily absentees according to EU reports. Many interdependent factors explain this situation: a weak added value given to schooling by families, parents' own traumatic school experience, poor parental expectations, importance of poverty, and social deprivation. School authorities and teachers still consider Gypsy pupils to be disruptive elements. As a consequence, these pupils are often enrolled in "ghetto schools" or in specific training programs with limited access to regular teaching.

\section{Perpignan: A Major European Concentration of Gypsy/ Roma Populations}

Like in the rest of the EU, a large proportion of French traveling communities has settled permanently. ${ }^{3}$ French citizens since the seventeenth century, they are estimated at between 300,000 and 400,000 people. They encompass five main subgroups that are also to be found in the European Union: Gypsies, Tziganes, Manouches, Romas, and Yeniches. Half of France's non-traveler population lives in the country's south and belongs to the Gypsy subgroup. In this article, I choose to

\footnotetext{
${ }^{3}$ According to a report of the French Senate (2011), non-travelers represent about a third of the Gypsy/Roma population in France.
} 
use the term Gypsy to designate the populations I am describing ${ }^{4}$ - first, because this group's members consider as such. They view the word Roma as a stigmatization strictly attached to nomadic groups from Eastern European countries (Romania and Bulgaria). Second, Gypsy refers to a set of cultural, linguistic, and geographic origins of former groups of travelers whose traditional area of travel covers the southern and eastern parts of Spain, and southern France.

The city of Perpignan is an interesting case study. With more than 10,000 people in the urban area (see Fig. 8.1), Gypsies in Perpignan constitute the most important and longstanding Gypsy community settled in France. They are mainly located in the central neighborhood of Saint-Jacques (with a population between 5000 and $6000)$, in two peripheral social housing complexes (2000) and in some small surrounding villages (see Fig. 8.1). Until World War II, this Catalan-speaking group was mostly semi-nomad. The group used to travel from Barcelona to Perpignan, subdivided into myriad families and clans on both sides of the French/Spanish

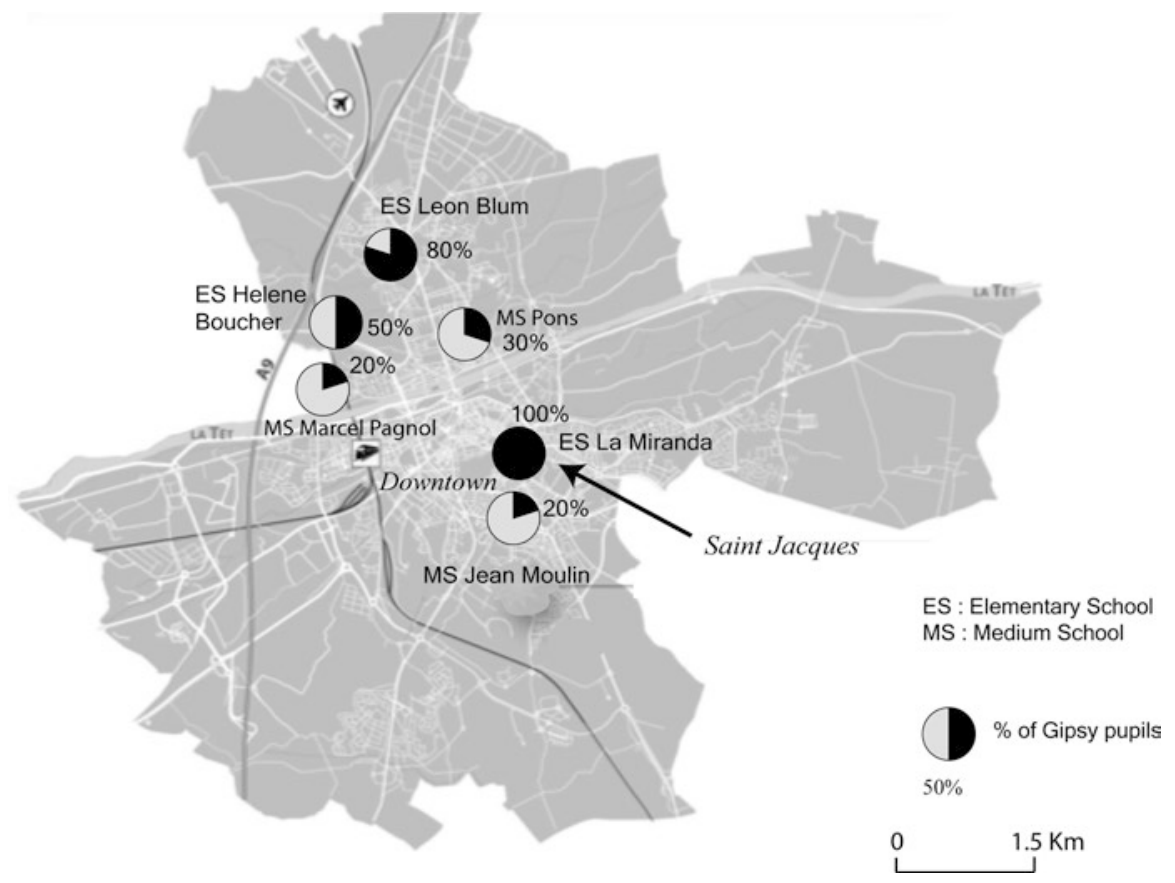

Fig. 8.1 Location of Gypsy pupils in Perpignan (2015). Source: Design by author

\footnotetext{
${ }^{4}$ Many scholars regard the term "Gypsy" as racist, carrying negative connotations, whereas they use "travelers" to cover a range of nomadic and seminomadic groups. However, in France "Roma" is used to refer to traveling groups that arrived from eastern Europe in the 1990s (mainly from Romania and Bulgaria). The term "Gypsy" can also be understood here as "Gypsy non-travelers."
} 
border. In 1942, the Nazi troops's invasion and the the Vichy regime's adoption of racist legislation led them to settle in urban locations in order to avoid deportation to concentration camps. They mainly settled in a central neighborhood of Perpignan: Saint-Jacques, a former Jewish neighborhood where they found available housing. They progressively lost their traditional jobs and skills and by the 1960s had become massively dependent on social assistance. Segregated and marginalized, this group has become the majority in Saint-Jacques, as the rest of the population has moved out to more comfortable dwellings elsewhere in the city and in new suburban locations. By the 1980s, Saint-Jacques had taken the shape of a mostly Gypsy neighborhood, populated by a poor and marginalized population, characterized by the massive presence of slums, ${ }^{5}$ high density occupation, a specific night life, and violence. ${ }^{6}$ As a space of advanced urban marginality, Saint-Jacques hosts those whom Loic Wacquant has depicted as "urban outcasts," accumulating social problems and ethnic stigmatization. In 2015, 2016, and 2017, the French National Bureau of Statistics classified Saint-Jacques as the poorest neighborhood in France. The socioeconomic indicators underline this longstanding urban marginalization: 74\% unemployment, an annual median income of €2200, literacy of $75 \%$, and a short life expectancy for men (61 years).

\section{The “Gypsy Territory,” Space of Educational Withdrawal? The Case of Saint-Jacques}

As a highly deprived neighborhood, Saint-Jacques is a "Gypsy territory" with symbolic, affective, political, but also social and ethnic dimensions that affect local educational issues in different ways. There are four main dynamics: place effects ("effets de lieu," Bourdieu, 1993), an unconscious view of school, tensions between the enclosed space of the community and the transactional space of school, and the co-building of a space of educational withdrawal.

\section{An Unconscious View of School, the Child King, and Place Effects}

Socioenvironmental settings are here structured by three interrelated factors: place effects, the importance given to the child king, and an unconscious view of school. First, place effects play a crucial role. I understand place effects as the set of constraints affecting educational and learning spaces (Bourdieu, 1993). Bourdieu

\footnotetext{
${ }^{5}$ The city of Perpignan reports 4400 slums in this neighborhood, about two thirds of the housing stock.

${ }^{6}$ This neighborhood hosts a big drugs market.
} 
underlined the need to take into account the spatial impacts of social groups. He argued that the position of groups, as dominant or dominated, is consolidated by place effects determined by the quality of space structures, dynamics, and social representations (Sélimanovski, 2009). Unhealthy housing, high density dwellings, run down streets and public spaces, lack of public and commercial facilities, and impoverishment have many consequences for education. With a high unemployment rate, dependency on social assistance, and a dominant street life, the child's life is unstructured and subject to many demands that are incompatible with school life and standards. The permanent presence of children in the streets, far from adult supervision, is a major barrier to compulsory schooling (see Fig. 8.2).

With my brother we go to bed by 3 or $4 \mathrm{AM}$, so we're too tired to go to school in the morning and my mom and dad want us to sleep ... We know it's not good for children to go to bed so late. But we can't wake up in the morning. ${ }^{\text {? }}$

Slum-like living conditions in a deprived urban space is part of the community destructuring process. This process is characterized by the weakened power of the clan chiefs (the "Tios"), replaced by the increasing influence of gangs of teenagers and drug dealers, and "the loss of the oral culture which used to transmit an educational minimum." " 7 The street as a public space where children are under adult supervision no longer acts as a customary and informal space of learning through the diffusion of an oral culture. Placed under the auspices of unstructured and uncontrolled groups of young boys and men, street life today replaces the traditional collective supervision of children by adults.

School absenteeism comes from that too: unhealthy houses, dads coming home late, the rhythm of life, so the kid follows that. In the community, it's less structured than before, the

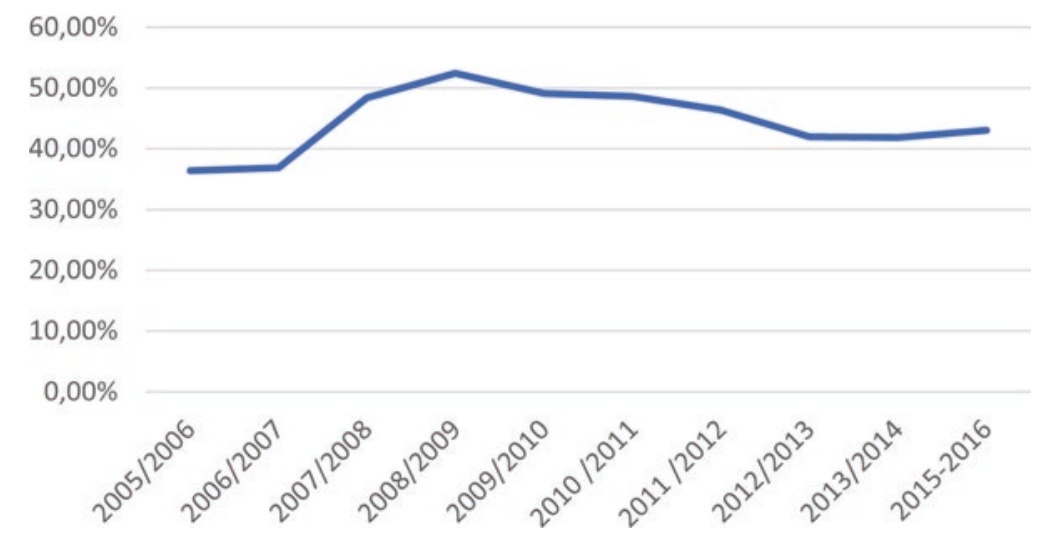

Fig. 8.2 Absenteeism, La Miranda Primary School (2005-2016). Source: Data provide by The Perpignan Department of Education. Source: Design by author

\footnotetext{
${ }^{7}$ Interview with N and M, 10 and 8 years old, March 19, 2017.

${ }^{8}$ Interview with a clan chief, March 20, 2017.
} 
old people have less authority. This lack of respect, it's mainly because of drugs that come here. Here, we can't do anything, today they deal in the Puig square (central square in the Gypsy neighborhood) and no one says a word. ${ }^{9}$

Saint-Jacques it's a muddled society. You spend your day muddling with others: parents, friends, neighbors, your wife, people in the street for a cigarette, for repairing your house, for a parking place, for a smoke of pot, for family allowances... so who cares for the Paios' school? ${ }^{10}$

The concentration and accumulation of social and economic problems fosters place effects that city social workers refer to as "the favela effect." They depict a mix of unfavorable spatial conditions and a specific kind of street life. This comparison with Brazilian favelas underlines place effects that arise from the presence of serious physical, cognitive, and symbolic barriers that have an impact on people's relationship with school.

Second, in this constrained sociospatial context, families develop individualist and consumerist behaviors that produce inter-familial rivalries over child consumerism. Families that face multiple fears seek reassurance by spending more on children (gifts, toys, clothes). Family education is thus structured from the child-king perspective, with few limits, including school performance and parental supervision. Many mothers and teachers interviewed report that school attendance depends on the child's willingness or on overprotective attitudes (e.g., no school when it rains or is cold or windy).

Third, an unconscious view of school structures the Gypsies' relationships to school, by which I mean the set of inherited cognitive structures specific to school experiences that act through immersion in a socioenvironmental setting (Bourdieu, 2000 , p. 2). The lack of school success stories in the group, the transmission of fears regarding school and academic teaching (failure, rejection, prejudices), a traumatic experience in school suffered by older generations, and the absence of educational role models all seriously limit school attendance (see Fig. 8.2). Fears are a powerful vector in this unconscious view of school. For this group, the school institution dehumanizes Gypsy pupils, nurturing a socioaffective dimension that is passed on from one generation to the next through the diffusion of collective myths ("teachers beat pupils," "they [teachers and educators] don't feed pupils and don't let kids drink when they are thirsty" ${ }^{11}$ ). Families consider the parental home (enlarged to include the street) to be a more secure environment for children than school, opposing the safe space of the streets of Saint-Jacques, which are controlled and only crowded by the community, to the insecurity of school-a space of symbolic violence.

\footnotetext{
${ }^{9}$ Woman, 50 years old, interview in an administrative report (Carrère, 2014, p. 23).

${ }^{10}$ Interview with Claude, man, 43 years old, March 20, 2017.

${ }^{11}$ Quoted in observation books, Ecole de la Miranda, Archives of the Perpignan department of education.
} 


\section{Saint-Jacques, Space of Educational Withdrawal}

Saint-Jacques can be depicted as a space of educational withdrawal, an expression I use to describe a co-building process that began in the 1960s. This process follows mutual strategies and agreements uniting municipal authorities (in charge of primary schools), state education officers (in charge of teachers' management, curriculum design and application), and community leaders (called "Tios" ${ }^{12}$ ).

On the one hand, educational withdrawal refers to a social and cultural process, well documented in the academic literature, explaining the traditional reluctance of Gypsies (travelers and non-travelers) towards school (Missaoui et al., 2002). These groups fear that school's normalizing role will produce a loss of identity. In France, school is designed according to a national and unique educational model. Following a republican and egalitarian policy, the same future is sought for each pupil, regardless of his or her socioeconomic environment. On the other hand, the term refers to the attitude of local authorities whose priority is usually to isolate Gypsy pupils from the rest of the school population, and who limit public investment in schools hosting Gypsy pupils. Gypsy pupils are seen as disruptive, with severe learning difficulties and a repellent effect on other groups. According to these mutual and implicit agreements, regulation of the neighborhood catchment area follows its own specific standards. Non-Gypsy families have benefited from special rules allowing them to avoid the two primary schools in this catchment area. Unlike other city catchment areas, where exceptions to the rules are strictly limited to three criteria, in this catchment area seven criteria make it easier for non-Gypsy families to avoid these schools. As a consequence, the two primary schools have become ethnicized with a very high proportion of Gypsy pupils (see Table 8.1). But paradoxically, the more these schools turn into Gypsy schools, the more Gypsy families consider school as a foreign institution. Many families describe these Gypsy schools as places of social relegation, as second-class schools popularly referred to as "cabanette" (little prison), which partly explains the low level of attendance (see Fig. 8.2).

State education officers and municipal authorities have never been inclined to control school attendance and to enforce the law in respect of compulsory schooling. They have adapted national education policies and standards to fit this specific space. They have implemented a territorialized public policy in light of territorial representations (a population unsuited to education, an enclosed and cultural defensive space, deviant cultural and educational attitudes rooted in a Gypsy ghetto logic). This territorialized public policy has led to acceptance of the Gypsy neighborhood as a distinct society entrenched in a specific place with limited educational expectations. Educational actors tacitly accept school absenteeism and regard massive drop-out rates as natural. This results in low-intensity educational policies whose implementers are mainly concerned with maintaining "social peace" and the status quo. This official position is in line with the attitude of the community, which is reluctant to accept compulsory education. These tacit and informal agreements

\footnotetext{
${ }^{12}$ Literally "uncles", here to be understood as chiefs of large family clans.
} 
Table 8.1 Irregular school attendance of Gypsy pupils and ethnic composition of schools (2015)

\begin{tabular}{lcl}
\hline Primary schools & Irregular school attendance* & \% of gypsy pupils \\
La Miranda & $54 \%$ & $100 \%$ gypsy \\
Léon Blum & $42 \%$ & $80 \%$ gypsy \\
Hélène Boucher & $35 \%$ & $50 \%$ gypsy \\
(Data: Department of Education, City of Perpignan, 2015) & \\
Secondary schools & Irregular school attendance* & $\%$ of gypsy pupils \\
Jean Moulin & $80 \%$ & Presence of "gypsy classes" \\
JS pons & $64,1 \%$ & $30 \%$ \\
Marcel Pagnol & $46.7 \%$ & $20 \%$ \\
(Data: Préfecture des Pyrénées Orientales, 2015) & \\
(* Pupils attending school less than 40\% of regular school time) \\
\multicolumn{3}{l}{} \\
School attendance (2008) & Morning & Afternoon \\
School attendance (2015) & $34 \%$ & $36.5 \%$ \\
\hline
\end{tabular}

Note. Source: Data: Department of Education, City of Perpignan, 2015. Design by author

are embedded in political patronage and are part of both institutional and community norms.

These multiple factors create a space of mutual educational withdrawal, both in formal and informal teaching spaces, assuring social peace, maintaining the group's cultural norms, and making the group doubly segregated (in urban and educational terms).

\section{Dialectic Relations Between the Enclosed Community Space and the Transactional Space of School}

The relationships of Gypsy families to school in Perpignan are structured by a set of tensions between the enclosed space of the community_physically and culturally embedded in this physical environment—and the school's transactional space. The community's enclosed space is one of the main drivers of the continuation of conservative norms, facilitating the imitation and reproduction of transgenerational life courses. It leads to a tacit recognition of the primacy of traditional oral and informal education over compulsory school education, justified by a long tradition of resistance against the world of the "paios" (non-Gypsy people). But the disappearance of the oral culture and of its spatial diffusion through informal learning spaces (streets, churches, community meetings, ...) seriously impacts this traditional relation to education. It has been replaced by daily censorship exerted by groups of peers ("la companya"), made up of groups of boys and young men located at street corners, against those who attend school regularly and are regarded as "deviant." The regular presence of visible and noisy groups in these narrow streets creates an 
urban space characterized by promiscuity and density, which facilitates the continued existence of a so-called community regulation of compulsory education.

Sometimes, my daughter goes to the middle school outside Saint-Jacques with her friends (non-Gypsy). "Where is she going to with the paias? Where is she going? Why do you let her go and do this?". You always have to struggle, because people said to her that she is a paia because she goes to school and even that she has different ideas. ${ }^{13}$

This boy was the first in ten years to attend high school in the community. When coming to high school he discovered his homosexuality. Now people in the street say: "Don't go to high school otherwise you'll become gay!"14

On the other hand, this conservative character is also subject to dynamics of transformation. Tensions arise between attachment to customary values considered as untouchable norms specific to the community, the "basis of a strong distinction from the world of 'paios' and constitutive of what makes the profession of Gypsy," 15 and the growing influence of French society. This influence brings new norms and values that diversely affect and destabilize the community and its relations to education and school: individualism, self-promotion, freedom of moral standards, consumption, and so forth. It also contributes to the diffusion of feelings of worthlessness in a community with a long history of segregation, poverty, and fearing having to meet official educational requirements and expectations. Behind these tensions, two frames of educational reference are at stake. The first is a specific frame of educational reference, positioning the child as an individual for whom school is expected to provide basic and utilitarian education needs (reading, writing, counting). The second is a mainstream frame of educational reference that is expected to provide more than learning these skills: individual social achievement. The urban settlement of Gypsies has led to school taking on an unprecedented role for this group, with alternating repulsion and fascination.

In this changing environment, school functions as a transactional space, especially for mothers who become involved in social interactions and make new contacts that allow them to distance themselves from the rest of the group. These interactions and transactions depend on the school's openness. Until the 2005 riots, schools' openness towards Gypsy families was quite limited, and dialogues with teachers were often based on mutual misunderstandings and conflicts.

\footnotetext{
${ }^{13}$ Woman, 32 years old, interview in an administrative report (Carrère, 2014, p. 23).

${ }^{14}$ Interview with S. Henry, social worker, head of the educational services for Gypsy pupils, City of Perpignan, September 6, 2017.

${ }^{15}$ Ibid.
} 


\section{Ethnic and Territorial Setting: A Tool for Educational Achievement?}

Changes occurred in the wake of the 2005 riots when community activists, social workers, and city officials decided to place school and educational issues at the center of restructuring the neighborhood.

\section{A Subversive Experiment: Saint-Jacques as an "Educator Quarter"}

In 2007, policymakers implemented a unique experimental process in Saint-Jacques with the support of national and local authorities, making educational issues the cornerstone of a wider expected change in the neighborhood. The project leaders aimed to build a new school hosting a unique educational project in France. They intended to reduce school absenteeism and to improve the relationships between Gypsy families and the school institution. Based on the Spanish experience with inclusive schooling of Gypsy pupils, the experimental educational policy in SaintJacques has been described by one of its promoters as a "subversive experiment," 16 aimed at turning Saint-Jacques into a fully-fledged educational stakeholder, officially recognized as an "educator quarter" (quartier éducateur). This experiment is based on the adaptation of learning and school rhythms to the specificities of the group and its socioeconomic environment. The new school (La Miranda School) has replaced the two former public schools, and is designed as a Gypsy school, hosting only pupils from the Gypsy community. The project leaders are seeking to open the school to its surrounding ethnic and social environment according to a specific curriculum and with school rhythms adapted to the community way of life. The curriculum includes lessons in Catalan, and fundamental subjects (French, mathematics) are taught in the afternoon (due to massive absenteeism in the morning) whereas the morning class focuses on welcoming activities. The school has hired adult intermediaries and educational assistants from the community, and the building hosts eight social workers, a health care program, a women's center, and a community job center. Mothers of first-grade children have access to the classrooms all day long. A bridging class has been added in order to prepare pupils for middle school, and the educational curriculum has been co-designed with social workers and community members. A walking school bus was set up ("pédibus de la Miranda") to collect the pupils from their homes. National and local authorities designed this educational project as the cornerstone of an urban renewal program financed by the French state (Programme de renouvellement urbain). The program leaders are aiming to deeply transform this deprived part of the city center with additional incentives such as

\footnotetext{
${ }^{16}$ Head of the municipal department of education, interview, March 20, 2017.
} 
housing rehabilitation and renovation of public space (400 houses to be rehabilitated or demolished, 200 million euros invested).

This innovative approach to the optimization of a socioenvironmental setting has been implemented according to three principles. First, the restructuring of the catchment area has led to a reorganization of the school system in the neighborhood: The two former primary schools have been closed, the catchment area and the neighborhood are strictly homogeneous, and a large educational center has been built hosting a kindergarten, a primary school, pre-school programs, and social services. Second, a highly profiled teaching staff (volunteer teachers with a specific professional background) has been set up. Third, the school project is widely open to the neighborhood and the Gypsy community. Teacher's involved in the Miranda school project suggest that "Gypsyness" ("gitanite"), the social and cultural practices of Gypsy families in local spaces (referred to as "Gypsy professionality" ${ }^{17}$ ), should encourage them to think of their profession outside the school and academic perimeters. They consider the surrounding environment as a territorial context that they can use as a pedagogical support, and clearly understand Gypsy territorial ethnicity as a component of the school's external resources. The project thus serves a dual purpose: The school has to open itself to the neighborhood by spreading out into the surrounding environment and it must open its doors to the family and the community. Families, mainly mothers, are allowed to stay in the classroom with their children, both in order to limit absenteeism and to familiarize them with educational issues.

\section{After 10 Years: Contrasted and Contested Results}

Obviously, the La Miranda experiment has supported the emancipation of women, mainly young mothers, and allowed an initial mobilization of fathers. The community's perception of schooling has partially changed. Fathers are no longer laughed at by their peers when they take their children to school. But these changes are still fragile and unstable. Men interested in education are still marginalized in the community, and subject to peer pressure to conform with tradition. Many communitybased educators and adults working as intermediaries and educational assistants find themselves in a difficult position between institutional requirements and community norms. Conservative community norms expressed by informal street groups such as "la companya" and relayed by male adults inside clans and families distort the nature of the experiment, drawing the picture of an attempt to remove women from men's control. These informal groups, located at strategic points such as street corners, with their daily street activities, spread rumors and challenge Gypsy educators, causing some of them to leave, and urging parents to conform with tradition. Fathers are an easy target for such groups, because they are accused of having no control over their wives. These changes reveal contradictions in the community

17 “Professionnalité gitane”. 
regarding education. I have observed a large range of attitudes and parental strategies. First, those who maintain strict conservative traditions and collective education norms are hostile to compulsory schooling. These families are highly reluctant to enroll their children in school, and consider school and formal instruction as useless for their "Gypsy professionality." Most still believe that a Gypsy "just needs to read, write, and count in order to get a driver's license." ${ }^{18} \mathrm{~A}$ second group of families, despite some reluctance and a real attachment to tradition, considers school enrollment as useful and as a source of social advancement and development for the whole family.

But school attendance is still inconsistent (Fig. 8.2 and Table 8.1) and subject to daily fluctuation depending on the family's nightlife, parental motivations, and overprotective cultural norms (no school when it is rainy or cold). The continuously deteriorating economic and social conditions create a climate that local people describe as "société de l'embrouille" (muddled society), in which everyone has to struggle. And there is a third group, made of the youngest families for whom education is the key to a better life, even if it involves leaving the community and the neighborhood. I observed that some families, the ones with higher educational expectations, develop specific school strategies. They enroll their children at La Miranda for the first to the third grades (in order to acculturate them to the school system) and then move them to more socially diverse schools outside the neighborhood. For these families (which are a minority), scared by the lack of perspectives, sending their children to schools outside the neighborhood anticipates a gradual exit from Saint-Jacques and the community.

In June 2017, 80 of the 200 school children enrolled at La Miranda were considered steady absentees, 20 already had or were about to enroll in another school outside the neighborhood, and 100 attended school on a regular basis.

\section{A Problematic "Gypsy Professionality" Disrupts the Analysis of Gypsy Educational Expectations}

Parents and teachers alike argue that one of the main challenges facing promoters of the Miranda experiment lies in the school's adaptation to the "Gypsy professionality." For teachers, this means the ability to understand and integrate community logics and the socioenvironmental settings into their professional practices. It involves an open attitude to parents' requests, such as the presence of mothers inside the classroom, a capacity to work with community intermediaries in the teacherparent relationship (education assistants belonging to the community, grandparents, uncles and aunts, members of the family clan, etc.).

The notion of "Gypsy professionality" occupies a central position in this dialectic relationship between school and the Gypsy community. Gypsies traditionally use

\footnotetext{
${ }^{18}$ Interview with a clan chief, September 12, 2017.
} 
and diffuse this term to depict their cultural specificities and their attachment to them. The group considers it to be one of the reasons behind their reluctance to accept compulsory schooling. Actors use it to refer to a specific way of life, a strong attachment to traditional norms and values in which the individual exists only through the collective life of the community. In the mid-2000s, when analyzing the educational problems and issues of Gypsies in Perpignan, a group of social workers trivialized the notion of "Gypsy professionality." They diffused and promoted a specific vision of this "Gypsy professionality" that observers consider as a folklorized vision of a complex reality. It spreads the idea that Gypsy families need differential treatment in education due to their specific cultural norms. This vision of Gypsy families' educational expectations under the auspices of a folklorized Gypsy professionality rapidly became problematic. It tends to lock the group in a position defined by stereotype social and spatial imaginaries, with negative impacts on school achievement.

The La Miranda experiment has not changed the nature of the problem. School attainment and enrollment are still weak, and the educational level remains very poor. Yet a majority of families have begun to accept schooling and learning. Of course, relationships to learning and schooling show great variability between families, depending on the time of the year, the nature and quality of the relationship forged between stakeholders, and their ability to deal with the resources and the limits of the community. They also depends on the quality of the socioenvironmental setting (community representations of school, tensions between schools, families and other community actors, the balance between stakeholders in providing pedagogical support, the quality of dwellings), and on the nature of the institutional context (financial and political support for the school from local authorities, external and continuous evaluation of pedagogical support, nature of the teaching staff, quality of teacher training).

One of the biggest problems is the lack of social mixing. If the absence of social mixing was a strategic choice at the beginning of the experiment (helping Gypsy pupils to learn at their own pace without external pressures and outside views, facilitating relationships between school, community and families), it turns into a disadvantage when students enroll in secondary schools. The gap between the experimental school and traditional middle schools, with a socially mixed school system and different educational standards and academic expectations, explains the high level of absenteeism in the sixth grade ( $45 \%$ to $80 \%$, see Table 8.1 ).

Many observers consider non-traveler Gypsies to now be trapped by policies of affirmative action, based on an "essentialist interpretation" of Gypsy educational issues. This tends to reduce the Gypsy community to a homogeneous and territorialized group. As I have mentioned, however, some families have adopted different school strategies, including going to schools outside the neighborhood. Policymakers have shaped the Miranda school model on the basis of special regulations, and the project has produced a lack of social mixing, although this is known to have produced positive effects in many other cases.

After 10 years, La Miranda school has once again become a "foreign institution" (Liégeois, 1997), a source of conflicts and residual violence, where school 
Table 8.2 5th-grade Gypsy pupils' levels of achievement, La Miranda Primary School (2006-2012)

\begin{tabular}{lll}
\hline & 2006 & 2012 \\
\hline $\begin{array}{l}\% \text { of 5th-grade pupils not able to understand an easy } \\
\text { text }\end{array}$ & 36 & 28.5 \\
$\begin{array}{l}\% \text { of 5th-grade pupils not able to reach the 2nd-grade } \\
\text { level of achievement }\end{array}$ & 62 \\
$\begin{array}{l}\% \text { of 5th-grade pupils not able to reach the 4th-grade } \\
\text { level of achievement }\end{array}$ & 56 & 52.4
\end{tabular}

Note. Source: Data: Department of Education, City of Perpignan, 2015. Design by author

drop-outs and non-attendance reach high levels (see Table 8.1). The poor academic results and weak school achievement (see Table 8.2) drive many families to consider school as useless in a local economy where Gypsies are unwelcome in any case. Assessing the La Miranda project as a failure, national education officers withdrew the project in 2015, transforming La Miranda School into a regular primary school that hosts only Gypsy pupils and that local Gypsies and paios alike consider a ghetto school.

\section{Conclusion}

Obviously, the institutional use of a social and ethnic environment is a complex lever for school attainment, impacting both the Gypsy community and the school in many ways. After decades of mutual ignorance and educational withdrawal, educational policymakers in Perpignan have abandoned the national and republican objectives of equity and social mixing to introduce more inclusive practices and ethno-oriented solutions. In the Miranda School experiment, the inclusion of the ethnic, cultural, and spatial environment has tended to maximize what Champollion (2015) calls territorial educational effects, and has speeded up changes. It has reinforced different trajectories between families. On the one hand, a small group (the most aware families), able to develop educational strategies, uses the La Miranda experiment to acculturate their children to school and to pave the way for their move to schools outside the community environment. On the other hand, a majority of families is still dependent on the cultural norms of the group and trapped by a complex and deprived environment. In all families, however, even those children who perform well at primary school tend to fail in middle and high schools. Similar conclusions have been reached regarding policies of educational inclusion in Spain. In Perpignan, as in Spain, the specificities of the Gypsy environment in the implementation of school reform seriously limit the capacity of families and pupils to access secondary education successfully.

This kind of experiment seems to be based on different professional groups (social workers, teachers) externally appraising the needs and opportunities of this ethnic minority by valuating a so-called Gypsy professionality that essentializes the group and its educational expectations. However, unexpected changes such as 
women's emancipation have eased educational concerns in young families, and thrown into question the group view of education. If this subversive experiment did not meet its objectives in terms of educational attainment and acceptance of compulsory schooling, some progress has been made in women's emancipation, and more broadly in the way families now consider educational issues.

\section{References}

Barreteau, O., Giband, D., Schoon, M., Cerceau, J., DeClerck, F., Ghiotti, S., James, T., Masterson, V. A., Mathevet, R., Rode, S., Ricci, F., \& Therville, C. (2016). Bringing together socialecological system and territoire concepts to explore nature-society dynamics. Ecology and Society, 21(4), 42. https://doi.org/10.5751/ES-08834-210442

Bourdieu, P. (1993). Effets de lieu [Effects of place]. In P. Bourdieu (Ed.), La misère du monde (pp. 159-167). Paris: Éditions du Seuil.

Bourdieu, P. (2000). L'inconscient d'école [The school unconscious]. Actes de la Recherche en Sciences Sociales, 135, 3-5. https://doi.org/10.3406/arss.2000.2696

Carrère, J.-P. (2014). Cahier des entretiens avec les familles: Etude d'impact du projet la Miranda [Family interview notebook: Impact study of the la Miranda project]. Perpignan: City of Perpignan, Education Nationale, Préfecture des PO.

Champollion, P. (2015). Education and territory: A conceptual framework. SISYPHUS: Journal of Education, 3(2), 12-27. https://doi.org/10.25749/sis.7882

Champollion, P., \& Legardez, A. (2010). Mieux prendre en compte les contextes territoriaux de l'école pour mieux adapter la formation des enseignants aux évolutions de la société et des élèves: L'exemple des espaces et territoires ruraux et montagnards [Taking better account of the territorial contexts for better adapting the training of teachers to the developments of society and students: The example of rural and mountainous spaces and territories]. In G. Baillat, D. Niclot, \& D. Ulma (Eds.), La formation des enseignants en Europe: Approche comparative (pp. 267-287). Brussels, Belgium: De Boeck Université. https://doi.org/10.3917/dbu. baill.2010.01

Charlot, B. (Ed.). (1994). L'école et le territoire: Nouveaux espaces, nouveaux enjeux [The school and the territory: New spaces, new challenges]. Paris: Armand Colin.

Debarbieux, B. (2009). Territoire-Territorialité-Territorialisation: Aujourd'hui encore, et bien moins que demain [Territory-Territoriality-Territorialization: Even today, and much less tomorrow]. In M. Vanier (Ed.), Territoires, Territorialité, Territorialisation: Controverses et perspectives (pp. 75-89). Rennes, France: Presses Universitaires de Rennes.

Di Méo, G. (1998). De l'espace aux territoires: Éléments pour une archéologie des concepts fondamentaux de la géographie [From space to territories: Elements for an archeology of the fundamental concepts of geography]. L'information géographique, 62, 99-110. https://doi. org/10.3406/ingeo.1998.2586

Di Méo, G., \& Buléon, P. (Eds.). (2005). L’espace social: Lecture géographique des sociétés [Social space: A geographic lecture on societies]. Paris: Armand Colin.

Fall, J. J. (2007). Lost geographers: Power games and the circulation of ideas within Francophone political geographies. Progress in Human Geography, 31, 195-216. https://doi. org/10.1177/0309132507075369

Faure, P. (2004). Population gitane et cadre scolaire [Gypsy population and school setting]. Ethnologie française, 34, 509-516. https://doi.org/10.3917/ethn.043.0509

Feu, J., \& Soler, J. (2002). Més enllà de 1'escola rural: Cap a un model integral i integrador de l'educació en el territori [Beyond the rural school: Towards an integral and integrative model of education in the territory]. Temps d'Educació, 26, 133-156. 
García Pastor, B. (2009). «Ser gitano» fuera y dentro de la escuela: Una etnografía sobre la educación de la infancia gitana en la ciudad de Valencia ["Being a Gypsy" outside and inside school: An ethnography on the education of Gypsy children in the city of Valencia]. Madrid: CSIC.

Garner, C. L., \& Raudenbush, S. W. (1991). Neighbourhood effects on educational attainment: A multilevel analysis. Sociology of Education, 64, 251-262. https://doi.org/10.2307/2112706

Lefebvre, H. (1974). La production de l'espace [The production of space]. Paris: Economica-Anthropos.

Liégeois, J.-P. (1985). Tsiganes et voyageurs: Données socio-culturelles, données socio-politiques [Gypsies and travelers: Sociocultural data, sociopolitical data]. Strasbourg: Council of Europe.

Liégeois, J.-P. (1997). Minorité et scolarité: Le parcours tsigane [Minority and schooling: The Gypsy journey]. Toulouse: Centre de Recherches Tsiganes/Centre Régional de Documentation Pédagogique de Midi-Pyrénées.

Lorcerie, F. (2009). L'école, son territoire et l'ethnicité [The school, its territory and ethnicity]. Revue Projet, 312, 64-71. https://doi.org/10.3917/pro.312.0064

Missaoui, H.-S., Missaoui, L., \& Tarrius, A. (2002). Mixités scolaires, mixités familiales et attitudes face à la déscolarisation d'enfants Gitans et Maghrébins [Mixed education, mixed families and attitudes towards the dropout of Gypsy and Maghreb children]. Perpignan: Institut Catalan de Recherche en Sciences Sociales.

Moracchini, C. (1992). Système éducatif et espaces fragiles: Les collèges dans les montagnes d'Auvergne [The educational system and fragile spaces: Secondary schools in the mountains of Auvergne]. Clermont-Ferrand, France: Centre d'Etudes et de Recherches Appliquées au MAssif Central, à la moyenne montagne et aux espaces fragiles.

O'Nions, H. (2010). Different and unequal: The educational segregation of Roma pupils in Europe. Intercultural Education, 21, 1-13. https://doi.org/10.1080/14675980903491833

Ormaux, S. (2008). Territoire et éducation: Une relation en mouvement [Territory and education: A relationship in motion]. Diversité, 155, 43-45.

Rickinson, M., Dillon, J., Teamey, K., Morris, M., Young Choi, M., Sanders, D., \& Benefield, P. (2004). A review of research on outdoor learning. Shrewsbury: Field Studies Council.

Rosário, P., Núñez, J. C., Vallejo, G., Azevedo, R., Pereira, R., Moreira, T., Fuentes, S., \& Valle, A. (2017). Promoting Gypsy children's behavioural engagement and school success: Evidence from a four-wave longitudinal study. British Educational Research Journal, 43, 554-571. https://doi.org/10.1002/berj.3271

Rothenburger, C. (2014). Enseigner en école rurale: Processus identitaires et développements professionnels d'enseignants du premier degré: Étude comparative dans quatre pays d'Europe et d'Amérique Latine [Teaching in rural schools: Identity processes and professional development of primary teachers: Comparative study in four countries in Europe and Latin America] (Doctoral dissertation). Lyon, France: Université Lumière Lyon 2.

Séchet, R., \& Veschambre, V. (Eds.). (2006). Penser et faire la géographie sociale: Contribution à une épistémologie de la géographie sociale [Thinking and doing social geography: Contribution to an epistemology of social geography]. Rennes, France: Presses Universitaires de Rennes. https://doi.org/10.4000/books.pur.362

Sélimanovski, C. (2009). Effets de lieu et processus de disqualification sociale: Le cas de Strasbourg et du Bas-Rhin [Effects of place and processes of social disqualification: The case of Strasbourg and the Bas-Rhin]. espace populations sociétés, 2009/1, 119-133. https://doi. org/10.4000/eps.3609

Sénat. (2011). L'intégration des Roms: Un défi pour l'Union européenne et ses États members [Roma inclusion: A challenge for the European Union and its Member States] (Rapport d'information $\mathrm{N}^{\circ} 199$ ). Paris: Sénat. 
Tarrius, A. (1997). Fin de siècle incertaine à Perpignan: Drogues, pauvreté, communautés d'étrangers, jeunes sans emplois, et renouveau des civilités dans une ville moyenne française [Uncertain end of the century in Perpignan: Drugs, poverty, communities of foreigners, unemployed young people, and a renewal of civility in a medium-sized French city.]. Perpignan: Le Trabucaire.

Wacquant, L. (2006). Parias urbains: Ghetto-Banlieues-État [Urban outcasts: GhettoSuburbs-State]. Paris: La Découverte.

Open Access This chapter is licensed under the terms of the Creative Commons Attribution 4.0 International License (http://creativecommons.org/licenses/by/4.0/), which permits use, sharing, adaptation, distribution and reproduction in any medium or format, as long as you give appropriate credit to the original author(s) and the source, provide a link to the Creative Commons license and indicate if changes were made.

The images or other third party material in this chapter are included in the chapter's Creative Commons license, unless indicated otherwise in a credit line to the material. If material is not included in the chapter's Creative Commons license and your intended use is not permitted by statutory regulation or exceeds the permitted use, you will need to obtain permission directly from the copyright holder.

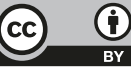

